\title{
ЯКІСТЬ ЖИТТЯ ХВОРИХ НА ХРОНІЧНУ ХВОРОБУ НИРОК УД СТАДІЇ, ЯКІ ЛІКУЮТЬСЯ ГЕМОДІАЛІЗОМ У ВЗАЄМОЗВ'ЯЗКУ 3 МЕЛАТОНІНУТВОРЮВАЛЬНОЮ ДИСФУНКЦІЄЮ ЕПІФІЗУ
}

\author{
КОНДРАТЮК В.Є., ПЕТРОВА А.С., КАРПЕНКО О.В. \\ Національний медичний університет імені О.О. Богомольця \\ Київ, Україна
}

Резюме

Ключові слова:

\begin{abstract}
Мета. Вивчення якості життя (ЯЖ) у пацієнтів з термінальною хронічною хворобою нирок (XXH), які лікуються методом гемодіалізу (ГД), у взаємозв'язку з мелатонінутворювальною функцією епіфізу (МФЕ).

Матеріали та методи. У дослідження включено 130 хворих, які лікуються методом

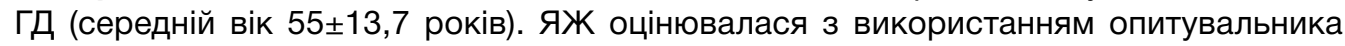
SF-36, модифікованого для хворих із нирковою патологією. Концентрація мелатоніну в слині визначалася імуноферментним методом із використанням набору Human MS (Melatonin Sulfate) ELISA Kit, Elabscience.

Результати та їх обговорення. Дослідження ЯЖ продемонструвало їі погіршення у 96\% обстежених хворих, що більшою мірою зумовлено симптомами «обтяжливого захворювання» та порушеннями МФЕ. Аналіз сумарного показника ЯЖ у хворих 3 порушеною МФЕ на 22,2\% ( $<<0,001)$ нижче за отриманий показник групи порівняння. Результат шкали «обтяжливість захворювання» та SF-12 групи з дисфункцією епіфізу на $57 \%(p<0,001)$ та 44,5\% (p<0,001) відповідно. Результат «фізичного сумарного компонента» групи основної групи на 58,4\% (p<0,001) нижчий за аналогічний компонент групи порівняння. Сума балів хворих основної групи за «психічним сумарним компонентом» на $32,3 \%(p<0,001)$ менша за результат хворих зі збереженою МФE.

Висновки. Встановлена залежність між погіршенням ЯЖ та порушенням МФЕ. Хворі на ГД із порушеною МФЕ характеризуються меншими величинами: сумарного показника ЯЖ, обтяжливості захворювання», SF-12, сумарних «фізичної компоненти» і «психічної компоненти», ніж у хворих зі збереженою МФЕ, відповідно на 22,2\%, $57 \%, 44,5 \%, 58,4 \%$ і 32,3\% (усі p<0,001), що свідчить про негативний вплив порушення циркадних ритмів мелатоніну на якість життя цієї важкої когорти пацієнтів. хронічна хвороба нирок, мелатонін, епіфіз, мелатонінутворювальна функція епіфізу, гемодіаліз, якість життя.
\end{abstract}

Вступ. Зростання поширеності хронічної хвороби нирок $(\mathrm{XXH}) €$ значною проблемою для системи охорони здоров'я, як для окремо взятої країни, так і всього світу загалом [1, 2]. Розвиток та прогресування XXH часто асоціюється з погіршенням якості життя (ЯЖ), що супроводжується змінами психологічної, фізичної та соціальноекономічної сфер життя пацієнта $[3,4]$.

ЯЖ являється важливою складовою концепції адекватності діалізної терапії та відображає ефективність проведених лікувально-реабілітаційних заходів $[5,6]$. Саме тому пошук нових методів лікування XXН та поліпшення ЯЖ хворих на нирково-замісній терапії залишається актуальним питанням сучасної медицини. Все більшу увагу, як науковців, так і практикуючих лікарів, привертає гормон епіфізу - мелатонін, що при- ймає участь у регуляції біологічних функцій всього організму $[7,8]$.

Проведені дослідження демонструють наявність прямих кореляційних зв'язків між рівнем мелатоніну та швидкістю клубочкової фільтрації $[9,10]$, що може свідчити про взаємозв'язок функціонального стану епіфізу та функції нирок [2].

Мета. Визначити ЯЖ у хворих на XXH V Д стадії, що лікуються методом гемодіалізу (ГД) та дослідити вплив дисфункції епіфізу на їі показники.

Матеріали та методи. У дослідження включено 130 (чоловіків - 65, жінок - 65) хворих з діагнозом XXH V стадії, що перебувають на амбулаторному лікуванні сеансами ГД у КНП «Київський міський центр нефрології та діалізу». 
При включенні хворих у дослідження використовувалися наступні критерії: чоловіки/жінки з хронічною хворобою нирок V Д стадії, що лікуються програмним ГД, вік старше 18 років, тривалість НЗТ $\geq 3$ місяців, тижневий діалізний час не менше 12 годин, показник адекватності ГД eKt/v $\geq 1,4$, потік крові на рівні 250-350 мл/хв, судинний доступ представлений артеріовенозноюфістулою [11].

Під час дослідження усім пацієнтам виконувалось стандартне обстеження, яке включало загальноклінічні, біохімічні та інструментальні методи дослідження.

Всім пацієнтам була визначена концентрація МТ в слині імуноферментним методом з використанням набору Human MS (Melatonin Sulfate) ELISA Kit, Elabscience. Забір проводили в денний та нічний час, переважно в весняно-літній період, при мінімальному освітленні 30 Ix.

ЯЖ оцінювалася за допомогою опитувальника SF-36, що складається з 36 питань основного модуля, доповнених багатопунктовими шкалами, створених для хворих із хронічною хворобою нирок, що лікуються діалізом («симптом/ проблеми», вплив ниркового захворювання на повсякденне життя, обтяжливість захворювання, когнітивні функції, професійний статус, сексуальна функція, якість соціальної взаємодії, сон). Всі хворі заповнювали анкету з послідовним пофакторним оцінюванням результатів та розрахунком індивідуального показника ЯЖ у балах (чим вищий бал, тим ліпша ЯЖ хворого).
Результати отримувалися за шкалами:

Симптом / проблеми (симптоми захворювання нирок) - "symptoms of kidney disease" (12 пунктів: №№ 17-28)

Вплив ниркового захворювання на повсякденне життя - "effect of kidney disease" (8 пунктів: №№ 29-36)

Обтяжливість захворювання - "burden of kidney disease" (4 пункти: №№ 13-16)

SF-12 (№№ 1-12) коротка форма загальної оцінки здоров'я

Розраховують наступні сумарні компоненти:

Фізичний сумарний компонент - "Physical health composite" (№№ 1-5, 8)

Психічний сумарний компонент - "Mental health composite" (№№ 6-7, 9-12) [2].

Відповіді оцінювалися в балах (від 0 до 100) 3 подальшим статистичним опрацюванням.

Проведене дослідження продемонструвало наявність добових особливостей порушення МФЕ у переважної більшості хворих на XXН V ст. (у 84,6\%), що лікуються методом ГД.

В залежності від функціонування епіфізу, для вирішення поставлених у роботі завдань сформовано дві групи дослідження. I групу (основну, $n=110$ ), склали хворі на XXН V Д стадії з порушеною МФЕ, в ІІ групу (порівняння, $\mathrm{n}=20$ ) увійшли хворі на XXH V Д стадії, з нормальною MФE.

Клініко-демографічна характеристика хворих, включених у дослідження, представлена в таблиці 1.

\section{Клініко-демографічна характеристика пацієнтів на ГД}

\begin{tabular}{|c|c|c|c|}
\hline Показник & $\begin{array}{c}\text { Хворі на XXН V Д стадії, } \\
\text { з порушеною МФЕ, n=110 }\end{array}$ & $\begin{array}{c}\text { Хворі на XXH V Д стадії, } \\
\text { зі збереженою МФЕ, n=20 }\end{array}$ & $\mathbf{p}$ \\
\hline Стать ч, абс., (\%) & $57(52 \%)$ & $8(40 \%)$ & 0,04 \\
\hline Вік, роки & $59[43 ; 67]$ & $54[48,5 ; 61,5]$ & 0,13 \\
\hline Тривалість лікування ГД, роки & $11,5[6 ; 14]$ & $7,5[4,5 ; 11]$ & 0,01 \\
\hline Стаж АГ & $14,5[8 ; 17]$ & $10[6 ; 14]$ & 0,04 \\
\hline $\mathrm{eKt} / \mathrm{V}$ & $1,44[1,42 ; 1,46]$ & $1,42[1,42 ; 1,44]$ & 0,04 \\
\hline IMT, кг/M2 & $21,43[20,3 ; 22,8]$ & $20[19,84 ; 21,21]$ & 0,01 \\
\hline Об’єм талії, см & $89[80 ; 93]$ & $80[77,5 ; 90]$ & 0,04 \\
\hline «Суха» вага, кг & $66,5[58 ; 75]$ & $57[53,5 ; 68,5]$ & 0,04 \\
\hline Міждіалізна прибавка ваги, кг & $3[2,7 ; 3,2]$ & $3,1[2,85 ; 3,25]$ & 0,19 \\
\hline Офісний середній САТ, мм рт ст & $158[142 ; 162]$ & $134[130 ; 137]$ & $<0,001$ \\
\hline Офісний середній ДАТ, мм рт ст & $90[80 ; 96]$ & $80[70 ; 87]$ & $<0,001$ \\
\hline Денний рівень мелатоніну, пг/мл & $1,8[1,5 ; 2,5]$ & $3,1[2,6 ; 3,5]$ & $<0,001$ \\
\hline Нічний рівень мелатоніну, пг/мл & $19,5[17,8 ; 29,7]$ & $111,0[97,3 ; 130]$ & $<0,001$ \\
\hline $\mathrm{Hb}, г / л$ & $85[76 ; 92]$ & $85,5[80,5 ; 94]$ & 0,3 \\
\hline Сатурація трансферину, \% & $32[22,6 ; 36,3]$ & $32,35[27,94 ; 36,05]$ & 0,9 \\
\hline ЗХ, ммоль/л & $4,4[3,11 ; 5,7]$ & $3,37[2,37 ; 5,26]$ & 0,05 \\
\hline ТГ, ммоль/л & $1,56[1,25 ; 1,78]$ & $1,3[1,2 ; 1,4]$ & 0,05 \\
\hline
\end{tabular}


Статистичний аналіз результатів дослідження проводився за допомогою програми SPSS Statistics Version 22.0.

Нормальність розподілу даних перевірялась за допомогою критерію Шапіро-Уілка. Дані вважалися такими, що відповідають нормальному розподілу, якщо результат цього тесту був $\mathrm{p}>0,05$.

Результати та обговорення. Аналіз показників ЯЖ у хворих на XXH V стадії, що лікуються ГД, продемонстрував невдоволеність загальним станом здоров'я, так як найнижча кількість балів визначалася за параметром «Обтяжливість захворювання», та в середньому складала 25 балів. Отримані нами результати свідчать про значний вплив захворювання пацієнтів на повсякденне життя, адже даний параметр характеризувався низькою кількістю балів (56 балів), меншою мірою на ЯЖ впливали симптоми захворювання нирок (68 балів). Оцінка загальних параметрів ЯЖ в обстеженій нами діалізній популяції характеризується, більшою мірою, зниженням фізичного сумарного компоненту, аніж психічного, що співпадає з дослідженнями інших авторів та продемонстровано в таблиці 2 [2].

Результати обстеження якості життя у хворих на XXH V стадії, що лікуються

Таблиця 2 гемодіалізом за опитувальником SF-36

\begin{tabular}{|l|c|}
\hline \multicolumn{1}{|c|}{ Параметри оцінки яЖ } & Хворі на ГД, $\mathbf{n = 1 3 0}$ \\
\hline Сумарний показник ЯЖ & $43,9[31,6 ; 53]$ \\
\hline Симптоми захворювання нирок & $67,7[56,3 ; 79,2]$ \\
\hline Вплив захворювання на життя & $56,3[43,8 ; 71,9]$ \\
\hline Обтяжливість захворювання & $25[6,3 ; 43,8]$ \\
\hline SF-12 & $34,6[19,6 ; 42,9]$ \\
\hline Фізичний сумарний компонент & $25[8,3 ; 37,5]$ \\
\hline Психічний сумарний компонент & $40[26,7 ; 58,3]$ \\
\hline
\end{tabular}

Для проведення подальшого дослідження хворі на ГД були розподілені на дві групи в залежності від функціонального стану епіфізу. За добовим профілем мелатоніну виявлено, що хворі основної групи, порівняно з хворими групи II, мають достовірно нижчий рівень МТ у слині: більш виражено в нічний період (на 82,4\%), ніж у денний (на 41,9\%) [11].

Аналіз сумарного показника ЯЖ у хворих 3 порушеною МФЕ на 22,2\% (p< 0,001) нижче за отриманий показник групи порівняння. Результат шкали «обтяжливість захворювання» та SF-12 групи з дисфункцією епіфізу на 57\% (p<0,001) та $44,5 \%$ ( $<0,001)$ відповідно, нижча за отриманий результат групи зі збереженою МФЕ. Параметр «Симптоми захворювання нирок» хворих 3 дисфункцією епіфізу на 3\% нижчий за аналогічний показник хворих зі збереженою МФЕ. Параметр оцінки ЯЖ «вплив захворювання на життя» хворих з порушеною МФЕ на 2,6\% нижчий за результат групи порівняння. Результат «фізичного сумарного компонента» групи з порушеною МФЕ на 58,4\% (p<0,001) нижчий за аналогічний компонент групи порівняння. Сума балів хворих з дисфункцією епіфізу за «психічним сумарним компонентом» на 32,3\% ( $<<0,001)$ менша за отриманий результат хворих зі збереженою МФЕ, що продемонстровано в таблиці 3 .

Таблиця 3

\section{Характеристика якості життя у хворих на XXН VД стадії в залежності від мелатонінутворювальної функції епіфізу}

\begin{tabular}{|l|c|c|}
\hline \multicolumn{1}{|c|}{ Параметри оцінки яЖ } & $\begin{array}{c}\text { Хворі на ГД з порушеною МФЕ, } \\
\mathbf{n = 1 1 0}\end{array}$ & $\begin{array}{c}\text { Хворі на ГД зі збереженою МФЕ, } \\
\mathbf{n = 2 0}\end{array}$ \\
\hline Сумарний показник ЯЖ & $39,9[29,9 ; 50,7]$ & $51,3[47,3 ; 60,7]^{*}$ \\
\hline Симптоми захворювання нирок & $67,7[56,2 ; 79,2]$ & $69,8[57,3 ; 78,1]$ \\
\hline Вплив захворювання на життя & $56,3[43,8 ; 71,9]$ & $57,8[42,2 ; 70,3]$ \\
\hline Обтяжливість захворювання & $18,8[6,3 ; 37,5]$ & $43,8[28,1 ; 50]^{*}$ \\
\hline SF-12 & $30,2[17,5 ; 38,8]$ & $54,4[42,9 ; 58,8]^{*}$ \\
\hline Фізичний сумарний компонент & $20,8[4,2 ; 33,3]$ & $50[39,6 ; 58,3]^{*}$ \\
\hline Психічний сумарний компонент & $37,5[26,7 ; 51,7]$ & $55,4[45,8 ; 62,1]^{*}$ \\
\hline
\end{tabular}

Примітка: * - достовірність між групами $\mathrm{p}<0,001$ 
Так, результати дослідження демонструють зниження параметрів шкали оцінки ЯЖ, більшою мірою, за рахунок пулу хворих з дисфункцією епіфізу, що свідчить про більш глибоке зниження ЯЖ у цій групі хворих.

3 метою більш детального розгляду факторів, що призводять до погіршення ЯЖ у хворих на XXH V стадії, що лікуються ГД, нами проведений аналіз взаємозв'язків між шкалами ЯЖ та клініко-лабораторними показниками. Так, був визначений слабкий прямий кореляційний зв'язок між рівнем Нb та шкалами «обтяжливість захво- рювання» та «SF-12» $r=0,182$ та $r=0,175$ відповідно, обидва $p<0,05$. Достовірні зв'язки між стажем діалізної терапії, віком хворих, значеннями кальцій-фосфорного обміну чи ліпідного спектру крові та шкалами опитувальника ЯЖ в даному дослідженні знайдені не були.

При проведені дослідження встановлено середній прямий кореляційний зв'язок між нічним рівнем мелатоніну та результатами «фізичного сумарного компоненту» $(r=0,53, p<0,001)$, що представлено на рис.1.

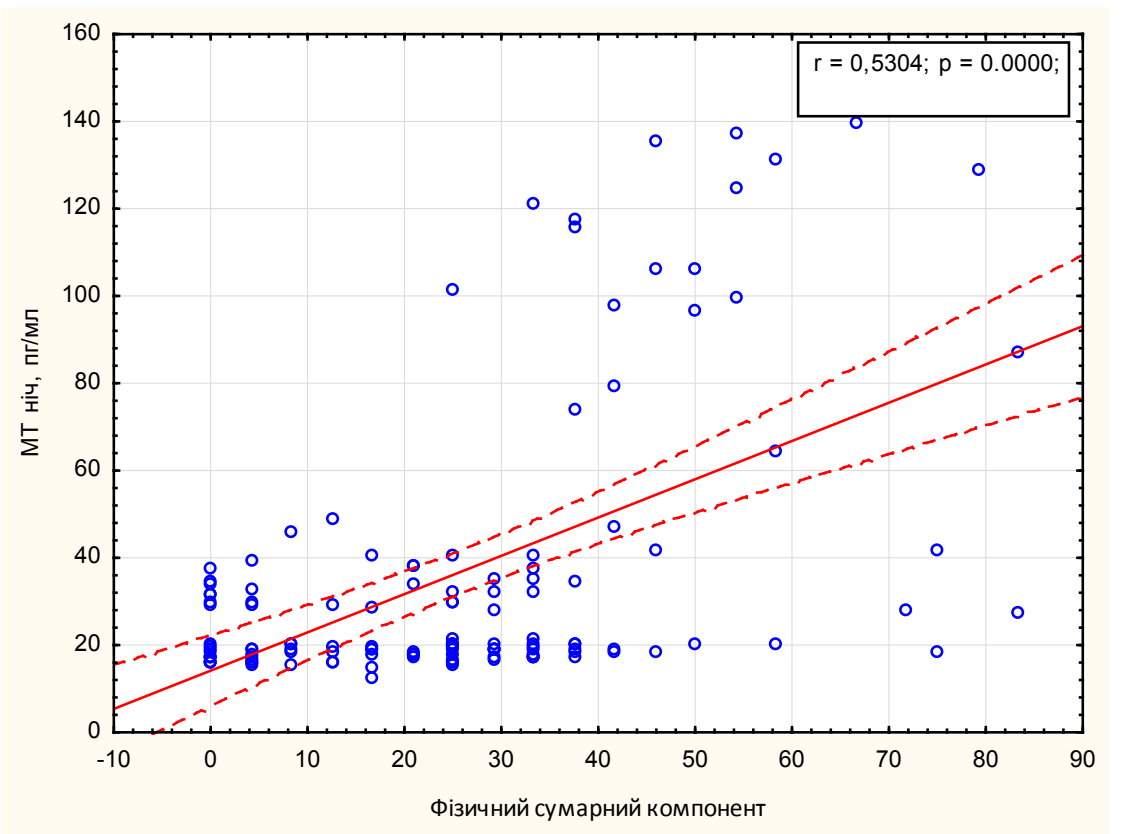

Рис. 1. Зв'язок рівнів нічного мелатоніну та «фізичного сумарного компоненту»

Встановлені позитивні слабкі кореляційні мелатоніну (ніч $r=0,278$; $p=0,004$; день $r=0,19$; зв'язки між значеннями «психічного сумарного $\mathrm{p}<0,05)$, що представлено на рис. 2. компоненту та денними й нічними показниками

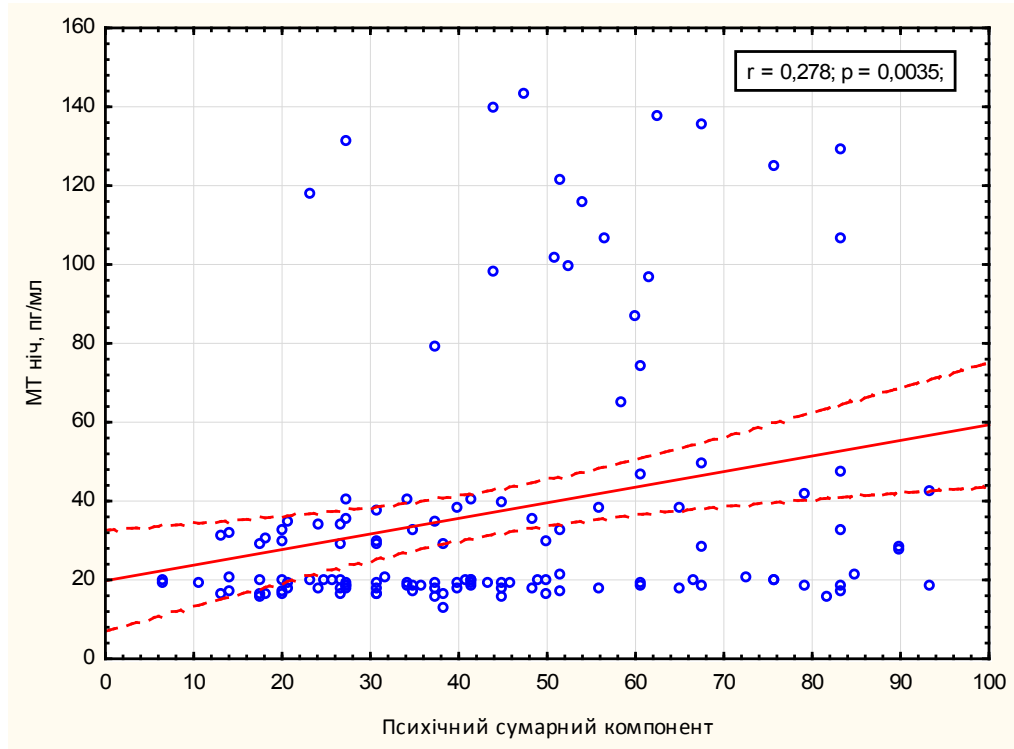

Рис. 2. Зв'язок рівнів нічного мелатоніну та « психічного сумарного компоненту» 
Аналіз сумарного показника ЯЖ проде- зв'язку з рівнями нічного мелатоніну $(r=0,326 ; p$ монстрував наявність прямого кореляційного =0,0099), що представлено на рис. 3.

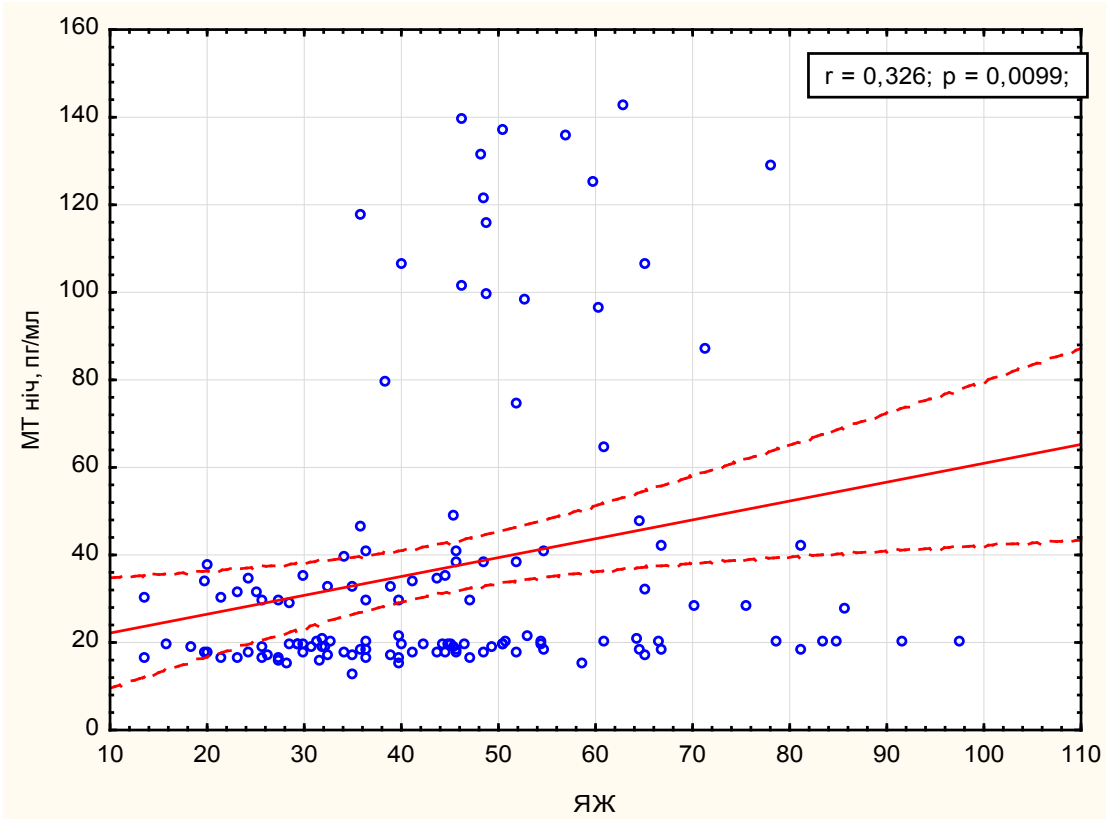

Рис. З. Зв'язок рівнів нічного мелатоніну та сумарного показника ЯЖ

Встановлені прямі кореляційні зв'язки між ня» та нічними рівнями мелатоніну $(r=0,286 ; p$ значеннями шкали «обтяжливість захворюван- =0,003), що представлено на рис. 4.

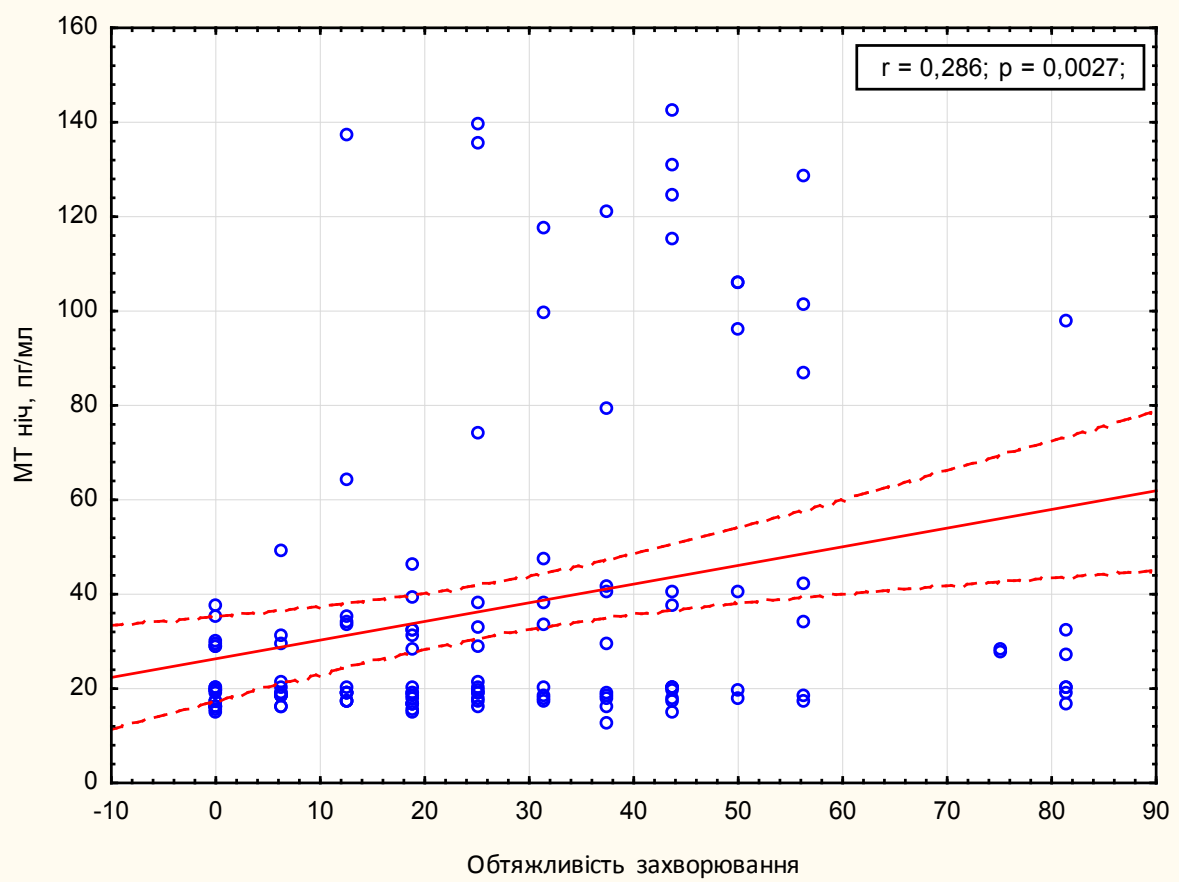

Рис. 4. Зв’язок рівнів нічного мелатоніну та шкали «обтяжливість захворювання»

Виявлено прямі кореляційні зв'язки між зна- і денним рівнями мелатоніну $(r=0,22 ; p=0,01)$, ченнями шкали SF-12 та нічним $(r=0,44 ; p<0,001)$ що представлено на рис. 5. 


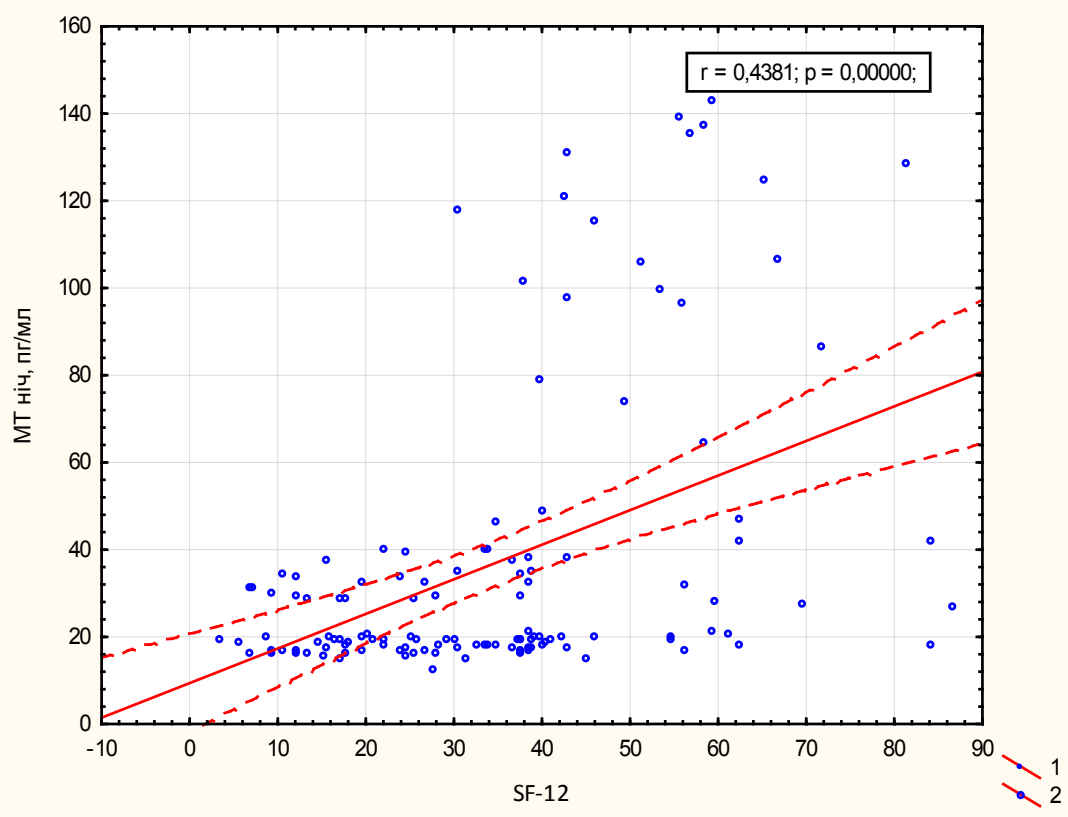

Рис. 5. Зв'язок рівнів нічного мелатоніну та шкали «SF-12»

Нами досліджено зв'язок значень ДМАТ та результатів, отриманих за шкалами опитувальника SF-36, котрий демонструє наявність обер- нених кореляційних зв'язків різної сили між показниками та шкалами, що продемонстровано в таблиці 4.

Таблиця 4

Кореляційний аналіз між показниками якості життя та добового моніторингу артеріального тиску

\begin{tabular}{|c|c|c|c|c|c|c|c|}
\hline Показник ДМАТ & 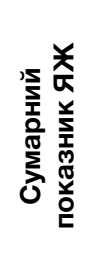 & 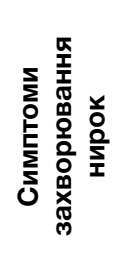 & 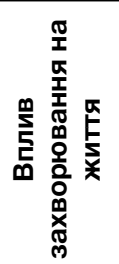 & 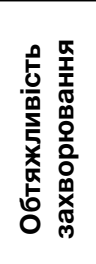 & 水 & 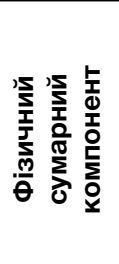 & 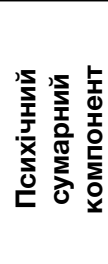 \\
\hline $\begin{array}{l}\text { Середній САТ (мм рт.ст.) } \\
\text { за добу }\end{array}$ & $-0,37$ & & & $-0,27$ & $-0,41$ & $-0,44$ & $-0,3$ \\
\hline $\begin{array}{l}\text { Середній САТ (мм рт.ст.) } \\
\text { в активний період доби }\end{array}$ & $-0,34$ & & & $-0,25$ & $-0,39$ & $-0,42$ & $-0,28$ \\
\hline $\begin{array}{l}\text { Середній САТ (мм рт.ст.) } \\
\text { в пасивний період доби }\end{array}$ & $-0,33$ & & & $-0,28$ & $-0,39$ & $-0,42$ & $-0,28$ \\
\hline $\begin{array}{l}\text { Середній ДАТ (мм рт.ст.) } \\
\text { за добу }\end{array}$ & & & & & $-0,26$ & $-0,31$ & \\
\hline $\begin{array}{l}\text { Середній ДАТ (мм рт.ст.) } \\
\text { в активний період доби }\end{array}$ & & & & & $-0,27$ & $-0,32$ & \\
\hline $\begin{array}{l}\text { Середній ДАТ (мм рт.ст.) } \\
\text { в пасивний період доби }\end{array}$ & & & & & $-0,25$ & $-0,31$ & \\
\hline \multicolumn{8}{|l|}{ ДІ САТ (\%) } \\
\hline \multicolumn{8}{|l|}{ ДІ ДАТ (\%) } \\
\hline \multicolumn{8}{|l|}{ Пульс } \\
\hline ВРП АТ & & & & $-0,18$ & $-0,19$ & $-0,2$ & \\
\hline Індекс часу \%, САТ & & & & & $-0,23$ & $-0,29$ & \\
\hline Індекс часу \%, ДАТ & & & & & $-0,22$ & $-0,29$ & \\
\hline
\end{tabular}


Проведений аналіз демонструє найбільшу кількість обернених кореляційних зв'язків між показниками ДМАТ зі шкалою опитувальника SF-12 та «фізичним сумарним компонентом», що може свідчити про вплив високих значень АТ на фізичну активність хворого та його загальний стан в цілому.
Аналіз зв'язку значень офісного САТ демонструє наявність обернених кореляційних зв'язків із показниками шкали «SF-12» $(r=-0,26 ; p<0,05)$, «фізичного сумарного компоненту» $(r=-0,29$; $p<0,05)$, що представлено на рисунку 6 та «психічного сумарного компоненту» $(r=-0,18 ; p$ $<0,05)$.

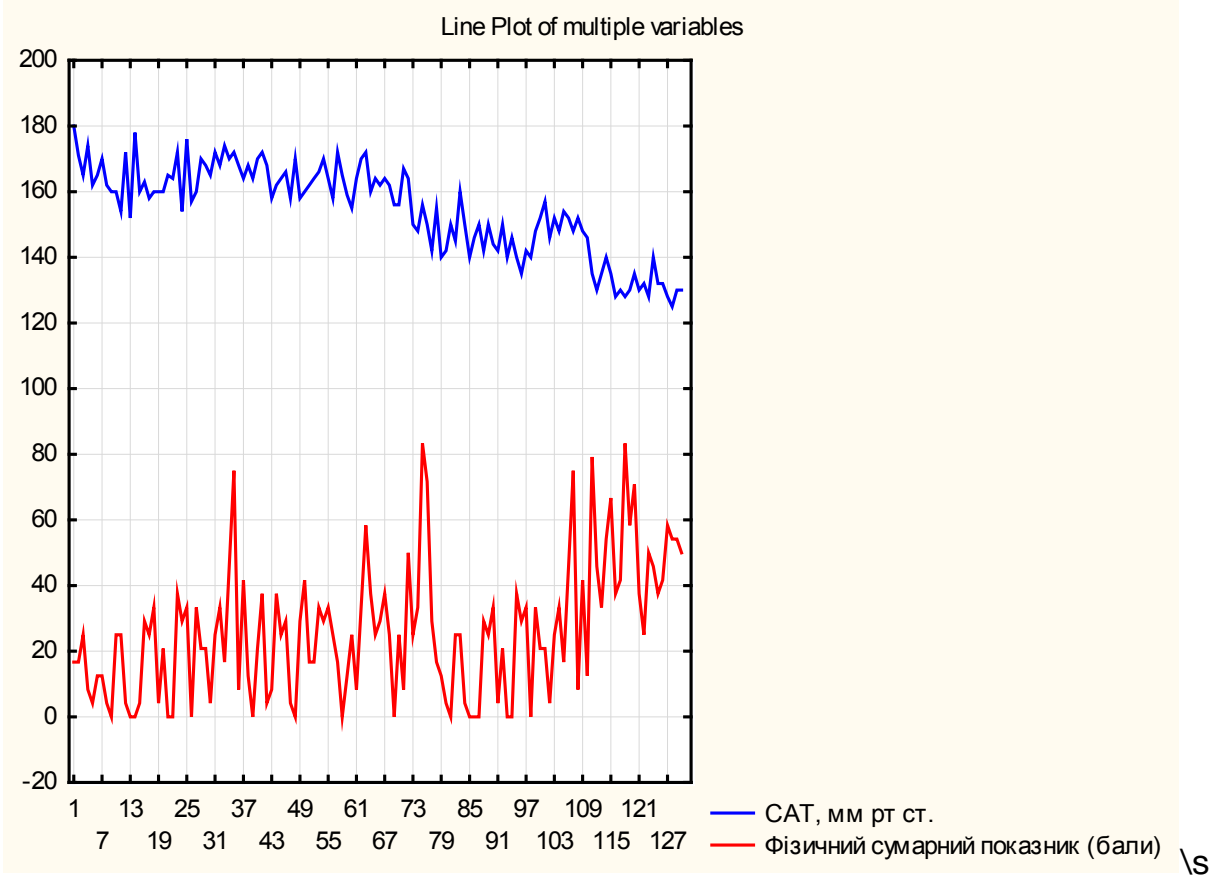

Рис. 6. Зв'язок значень офісного CAT та показників шкали «SF-12»

Схожі результати отримали при аналізі кореляційних зв'язків між рівнем офісного ДАТ та показниками шкали «SF-12» $(r=-0,303 ; p<0,05)$, «фізичного сумарного компоненту» $(r=-0,33$; $p<0,05)$ та «психічного сумарного компоненту» $(r=-0,21 ; p<0,05)$.

Аналіз кореляцій продемонстрував наявність обернених зв'язків між рівнем офісного ПАТ та показниками шкали «SF-12» $(r=-0,18 ; p<0,05)$, шкали «обтяжливість захворювання» $(r=-0,17$; $p<0,05)$, «фізичного сумарного компоненту» $(r=$ - 0,19; $p<0,05)$ та сумарним показником ЯЖ $(r=-$ $0,204 ; p<0,05)$.

Результати проведеного дослідження демонструють значне погіршення ЯЖ у хворих на XXH V cт., що лікуються гемодіалізом, що детермінується прогресуванням анемії, високим значеннями ДМАТ, офісного САТ, ДАТ та ПАТ й глибиною порушення МФЕ, що більш виражено за рівнем нічного МТ.

\section{Висновки:}

Порушення якості життя (ЯЖ) і мелатонінутворювальної функції епіфізу (МФЕ) виявляється відповідно у 96\% і 84,6\% хворих на XXH V стадії, що знаходяться на лікуванні ГД.
У хворих на ГД погіршення ЯЖ більшою мірою детермінується симптомами, пов'язаними 3 «обтяжливістю захворювання».

Встановлена залежність між погіршенням ЯЖ та порушенням МФЕ. Хворі на ГД із порушеною МФЕ характеризуються меншими величинами: сумарного показника ЯЖ, “обтяжливості захворювання», SF-12, сумарних «фізичної компоненти» і «психічної компоненти», ніж у хворих зі збереженою МФЕ відповідно на 22,2\%, 57\%, $44,5 \%, 58,4 \%$ і 32,3\% (усі p< 0,001), що свідчить про негативний вплив порушення циркадних ритмів мелатоніну на якість життя цієї важкої когорти пацієнтів.

\section{ЛITEPATУРA}

1. Дудар І.О., Паламар Б.І., Красюк Е.К., Петрова А.С. Поширеність XXН VД стадії у світі та в Україні. Здоров'я України. 2015 (34): 10-12.

2. Кондратюк В.Є., Петрова А.С. Оцінка якості сну та життя у пацієнтів з хронічною хворобою нирок, що знаходяться на лікуванні методом гемодіалізу. Актуальні проблеми нефрології. 2018. (24): 37-40. 
3. Smirnov A.V. Zamestitel'naja pochechnaja terapija. Nefrologija. 2011; 1: 33-46. [In Russian].

4. Kondratiuk V., Petrova A. Characteristics of melatonin-forming disorders of the epiphysis in hemodialysis patients depending on clinical and demographic parameters. Ukrainian Journal of Nephrology and Dialysis. 2020; 1 (65): 36-47. doi: 10.31450/ukrjnd.1(65).2020.06 (https://ukrjnd.com.ua/index.php/journal/article/view/390/285 )

5. Sayaka Ishigaki, Naro Ohashi, Takashi Matsuyama, and other, Melatonin ameliorates intrarenal renin-angiotensin system in a 5/6 nephrectomy rat model. Clinical and Experimental Nephrology. November 2017. 22(3): 539-549. DOI: 10.1007/s10157-017-1505-7.

6. Кондратюк В.Є., Петрова А.С., Карпенко О.В. Характеристика мелатонінутворювальної функції епіфіза у пацієнтів 3 хронічною хворобою нирок у термінальній стадії. Клінічна ендокринологія та ендокринна хірургія. 2019. (4): 94-102. DOI: https://doi. org/10.30978/CEES-2019-4-94

7. Byjean A. Boutin. How Can Molecular Pharmacology Help Understand the Multiple Actions of Melatonin: 20 Years of Research and Trends. November 21st 2018: 13-21. DOI: 10.5772/intechopen.79524.

8. Jihwan Myung, Mei-Yi Wu, Chun-Ya Lee, Amalia Ridla Rahim, Vuong Hung Truong, Dean Wu, Hugh David Piggins, Mai-Szu Wu. The Kidney Clock Contributes to Timekeeping by the Master Circadian Clock. nt. J. Mol. Sci. 2019, 20(11), 2765; https://doi.org/10.3390/ ijms20112765

9. Cipolla-Neto, Fernanda Gaspar do Amaral. Melatonin as a Hormone: New Physiological and Clinical Insights. Endocrine Reviews, Volume 39, Issue 6, December 2018: 9901028. https://doi.org/10.1210/er.2018-00084.

10. Каладзе Н.Н., Слободян Е.И., Говдалюк А.Л. Эпифизарный гормон мелатонин и хроническая болезнь почек (обзор литературы и собственные исследования). Журнал «Здоровье ребенка» 2 (61). 2015: 183-188.

11. Кондратюк В.Є., Петрова А.С., Карпенко О.В. Клінічна оцінка порушень мелатонінутворювальної функції епіфізу та анемії у хворих на хронічну хворобу нирок 5 стадії, що лікуються гемодіалізом. Нирки. 2020. 9(1): 20-28.

\section{PЕЗЮME}

\section{КАЧЕСТВО ЖИЗНИ БОЛЬНЫХ С ХРОНИЧЕСКОЙ БОЛЕЗНЬЮ ПОЧЕК V Д СТАДИИ, КОТОРЫЕ ЛЕЧАТСЯ ГЕМОДИАЛИЗОМ ВО ВЗАИМОСВЯЗИ С МЕЛАТОНИНОБРАЗОВАТЕЛЬНОЙ ДИСФУНКЦИЕЙ ЭПИФИЗА}

Кондратюк В.Е., Петрова А.С., Карпенко О.В.

\author{
Национальный медицинский университет \\ имени А.А. Богомольца (Киев, Украина)
}

Цель. Изучение качества жизни (КЖ) у пациентов с терминальной хронической болезнью почек (ХБП), которые лечатся методом гемодиализа (ГД) и определить ее взаимосвязь с мелатониобразовательной функцией эпифиза (МФЭ).

Материалы и методы. В исследование включено 130 больных, которые лечатся методом ГД (средний возраст $55 \pm 13,7$ лет). КЖ оценивалось с использованием опросника SF-36, модифицированного для больных с почечной патологией. Концентрация мелатонина в слюне определялась иммуноферментным методом с использованием набора Human MS (Melatonin Sulfate) ELISA Kit, Elabscience.

Результаты. Исследования КЖ продемонстрировало ее ухудшение у 96\% обследованных больных, в большей степени обусловлено симптомами "обременительности заболевания» и нарушениями МФЭ. Анализ суммарного показателя $\mathrm{K} Ж$ у больных с нарушенной МФЭ на 22,2\% ( $p<0,001)$ ниже полученного показателя группы сравнения. Результат шкаль «обременительность заболевания» и SF-12 группы с дисфункцией эпифиза на $57 \%$ ( $><0,001)$ и 44,5\% (р <0,001) соответственно. Результат «физического суммарного компонента» группы основной группы на $58,4 \%$ ( $p<0,001)$ ниже аналогичного компонента группы сравнения. Сумма баллов больных основной группы по «психическому суммарному компоненту» на $32,3 \%$ ( $p<0,001)$ меньше результата больных с сохраненной МФЭ.

Выводы. Установлена зависимость между ухудшением КЖ и нарушением МФЭ. Больные ГД с нарушенной МФЭ характеризуются меньшими величинами: суммарного показателя KЖ, тяжести заболевания, SF12, суммарных «физической компоненты» и «психической компоненты», чем у больных с сохраненной МФЭ соответственно на 22,2\%, 57\%, 44,5\%, 58,4\% и 32,3\% (все $\mathrm{p}<0,001)$, что свидетельствует о негативном влиянии нарушения циркадных ритмов мелатонина на качество жизни этой тяжелой когорты пациентов.

Ключевые слова: хроническая болезнь почек, мелатонин, эпифиз, мелатонинобразовательная функция эпифиза, гемодиализ, качество жизни. 


\section{SUMMARY}

\section{QUALITY OF LIFE OF PATIENTS WITH CHRONIC KIDNEY DISEASE VD STAGES TREATED HEMODIALYSIS IN THE RELATIONSHIP WITH MELATONIN-FORMING DYSFUNCTION OF THE EPIPHYSIS \\ Kondratiuk V.E., Petrova A.S., Karpenko O.V.}

Bogomolets National Medical University (Kyiv, Ukraine)

Goal. To study the quality of life (QOL) in patients with end-stage chronic kidney disease (CKD) who are treated with hemodialysis (HD) and to determine its relationship with the melatonic function of the pineal gland.

Materials and methods. The study included 130 patients who are treated with the HD method (mean age 55 \pm 13.7 years). QOL was assessed using the SF-36 questionnaire modified for patients with renal pathology. The concentration of melatonin in saliva was determined by the enzyme immunoassay using the Human MS (Melatonin Sulfate) ELISA Kit, Elabscience.

Results and discussion. QoL studies demonstrated its deterioration in $96 \%$ of the examined patients, to a greater extent due to the symptoms of "burdensome disease" and MPE disorders. Analysis of the total QOL indi- cator in patients with impaired MFE is $22.2 \%$ ( $p<0.001)$ lower than the obtained indicator in the comparison group. The result of the scale «burden of disease» and SF-12 groups with pineal gland dysfunction by $57 \%$ ( $p$ $<0.001)$ and $44.5 \%(p<0.001)$, respectively. The result of the «physical total component" of the group of the main group is $58.4 \%(p<0.001)$ lower than the similar component of the comparison group. The sum of the scores of the patients in the main group for the «mental total component» is $32.3 \%(p<0.001)$ less than the result of patients with preserved the melatonic function of the pineal gland.

Conclusions. The relationship between the deterioration of QOL and the violation of MFE was established. Patients with HD with impaired MFE are characterized by lower values: total QOL, severity of the disease, SF-12 total «physical components» and «mental components» than in patients with preserved MFE by $22.2 \%, 57 \%$, $44.5 \%$, respectively, $58.4 \%$ and $32.3 \%$ (all $p<0.001$ ), which indicates the negative impact of disturbances in the circadian rhythms of melatonin on the quality of life of this severe cohort of patients.

Key words: chronic kidney disease, melatonin, pineal gland, melatonin-forming function of the pineal gland, hemodialysis, quality of life.

\section{АВТОРСЬКА ДОВІДКА}

\section{Кондратюк Віталій Євгенович}

Національний медичний університет імені О.О. Богомольця, завідувач кафедри, д.м.н., професор моб.: +380503872902

E-mail: kondratiuk_v@ukr.net

\section{Петрова Анна Сергіївна}

Національний медичний університет імені О.О. Богомольця, к.М.н., асистент

моб.: +380931971748

E-mail: anna2311doc@ukr.net

Карпенко Олена
В’ячеславівна
Національний медичний університет
імені О.О. Богомольця, к.м.н,,
доцент
моб.: +380957199007
E-mail: karpenko05.12@ukr.net

\section{Кондратюк Виталий Евгеньевич}

Национальный медицинский университет имени А.А. Богомольца, заведующий

кафедры, д.м.н., профессор

моб.: +380503872902

E-mail: kondratiuk_v@ukr.net

\section{Петрова Анна Сергеевна}

Национальный медицинский университет имени А.А. Богомольца, K.M.H.,

ассистент

моб.: +380931971748

E-mail: anna2311doc@ukr.net

\section{Карпенко Елена Вячеславовна}

Национальный медицинский университет имени А.А. Богомольца, K.M.H.,,

доцент

моб.: +380957199007

E-mail: karpenko05.12@ukr.net

\section{Kondratiuk Vitaliy}

National Medical University named after O. Bogomolets, head of Department, $M D$, Professor

mob.: +380503872902

E-mail: kondratiuk_v@ukr.net

\section{Petrova Anna}

National Medical University named after O. Bogomolets, Ph.D., assistant mob.: +380931971748

E-mail: anna2311doc@ukr.net

\section{Karpenko Olena}

National Medical University named after O. Bogomolets, Ph.D., docent mob.: +380957199007

E-mail: karpenko05.12@ukr.net

Стаття надійшла до редакції 3.01.21p. 